of museum staffs, and the impressive list of publications, including those in the Annals of the South African Museum, bears witness to extensive activity in this direction.

\section{Radiation Hazards in Industry: Conference in London}

THE third conference of the British Occupational Hygiene Society will be a one-day meeting on "Radiation Hazards in Industry", to be held in the London School of Hygiene and Tropical Medicine on November 1. The conference is open to non-members (on payment of a fee of one guinea) as well as to members of the Society. The chair will be taken by the president of the Society, Prof. E. J. King, professor of chemical pathology in the Postgraduate Medical School, University of London. Four papers will be presented as follows: the health of workers exposed to ionizing radiation, by A. S. McLean, principal medical officer, Department of Atomic Energy; radiation safety in the Industrial Group of the Department of Atomic Energy, by D. R. R. Fair, head of the Health Physics Division, Department of Atomic Energy, Windscale Works, Sellafield; protection against $X$-rays and gamma-rays in the industrial field, by W. Binks, Radiological Protection Service, Ministry of Health and Medical Research Council; and safety criteria in atomic energy, by F. R. Farmer, assistant director (production), Department of Atomic Energy, Industrial Group Headquarters, Risley. There will be a short discussion after each paper. The conference will be reported, in due course, in the British Journal of Industrial Medicine. Those intending to be present should complete and return by October 25 the appropriate form, obtainable from the honorary treasurer, Mr. D. E. Hickish, London School of Hygiene and Tropical Medicine, Keppel Street, London, W.C.1.

\section{Biology and a General University Education}

A Residential conference is being arranged by the Institute of Biology in co-operation with members of the staff of the University College of North Staffordshire on the place of biology in a general university education. The meeting will take place at the University College of North Staffordshire during December 19-21. Part of the programme will revolve around the place of biology in a general science course at university-level, while the remainder of the programme will be concerned with the place of biology in a university educesion which is not primarily scientific. Among those expected to take part will be Dr. J. Hutchins, professor of physiology in the University of Chicago, who has been closely concerned with the planning and teaching of a course in biology for arts students, Prof. S. Zuckerman, Prof. A. R. Gemmell, Dr. C. Gordon, Mr. L. J. F. Brimble, Mr. W. B. Yapp, Prof. J. F. Danielli, Prof. T. A. Bennet-Clark and Prof. F. W. Rogers Brambell. Further information can be obtained from the Secretary, Institute of Biology, Tavistock House South, Tavistock Square, London, W.C.1.

Fourteenth International Congress of Pure and Applied Chemistry, Zurich

THE dates of the Fourteenth International Congress of Pure and Applied Chemistry and the Eighteenth Conference of the International Union of Pure and Applied Chemistry, both of which will be held in Zurich, are July 21-27 and July 20-28, 1955, respectively (and not the other way round, as given in Nature of September 25, p. 588). Papers will be limited to twenty minutes and summaries not exceeding 250 words should be submitted via the appropriate national organization. The final dates of acceptance vary for the different countries from December 15 and January 31 , but in any event the summaries must reach the Congress secretary-general by February 15.

\section{Announcements}

ThE Committee of Privy Council for Agricultural Research and Nature Conservation has appointed Mr. Frank Rayns to fill a vacancy in the membership of the Agricultural Research Council, caused by the retirement of Prof. K. Mather. Mr. Rayns is director of the Norfolk Agricultural Station, Sprowston; he: is chairman of the Experimental Husbandry Committee of the Agricultural Improvement Council for England and Wales and serves on the governing body of the National Institute of Agrieultural Engineering. Prof. S. Zuckerman has been appointed a member of the Agricultural Research Council for a further term of office.

Dr. Nicol Gross, managing director of S.A.G. (Pty.), Ltd., Johannesburg, has been appointed to the University of London readership in production engineering tenable at the Imperial College of Science and Technology.

Mr. Ivor Bowen has retired from the post of principal director of Equipment Research and Development (Air) in the Ministry of Supply, and is taking up an appointment with the General Precision Equipment Corporation of the United States; his new post will be in London.

THE Third International Congress on Vitamin E will be held in Milan in September 1955. The fol. lowing topics will be discussed: vitamin $\mathrm{E}$ and metabolic processes; influence of vitamin $\mathrm{E}$ on the hæmato-vascular system; vitamin $\mathbf{E}$ and the neuromuscular system; correlation between vitamin $\mathrm{E}$ and other vitamins and hormones. Further information can be obtained from Prof. Emilio Raverdino, via Pietro Verri 4, Milan.

THE Rockefeller Foundation has made a grant of 7,500 dollars to the University of Glasgow towards the expenses of three small working conferences of European scientists interested in genetical problems. The conferences will be held during the next five years, one probably in or near Glasgow and the others in localities to be decided.

Three postdoctoral fellowships in statistics are being offered for 1955-56 by the University of Chicago. The purpose of these fellowships (of value 4,000 dollars each) is to acquaint established research workers in the biological, physical and social sciences with the role of modern statistical analysis in the planning of experiments and in the analysis of empirical data. Application forms can be obtained from the Committee on Statistics, University of Chicago, Chicago 37, and must be returned by February 15, 1955.

ERRATum. In the communication "Seasonal Regulation in British Dragonflies" by P. S. Corbet in Nature of October 2, p. 655, the labelling of the axes of the graph should be interchanged; thus the ordinates indicate percentage of yearly population emerging per day, and the abscissæ successive days of emergence. 